$\mathrm{DE}$

M E D I C I N A

T R O P I C A L

$\mathrm{DE}$

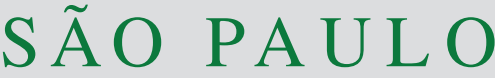

JOURNAL OF THE SÃO PAULO INSTITUTE OF TROPICAL MEDICINE

1 Universidade Federal do Rio Grande do Sul, Faculdade de Veterinária, Centro de Diagnóstico e Pesquisa em Patologia Aviária, Porto Alegre, Rio Grande do Sul, Brazil

2Universidade Federal do Rio Grande do Sul, Instituto de Ciências e Tecnologia de Alimentos, Porto Alegre, Rio Grande do Sul, Brazil

${ }^{3}$ Universidade de Passo Fundo, Medicina Veterinária, Passo Fundo, Rio Grande do Sul, Brazil

Correspondence to: Bruna Webber Universidade Federal do Rio Grande do Sul, Faculdade de Veterinária, Centro de Diagnóstico e Pesquisa em Patologia Aviária, Av. Bento Gonçalves, 9090, CEP 90040-060, Porto Alegre, RS, Brazil Tel: +555133086138

E-mail: brunahw@ hotmail.com

Received: 4 April 2019

Accepted: 27 June 2019

\section{Detection of virulence genes in Salmonella Heidelberg isolated from chicken carcasses}

Bruna Webber $^{1}{ }^{10}$, Karen Apellanis Borges ${ }^{1}$, Thales Quedi Furian', Natalie Nadin Rizzo', Eduardo Cesar Tondo ${ }^{2}$, Luciana Ruschel dos Santos ${ }^{3}$, Laura Beatriz Rodrigues ${ }^{3}$, Vladimir Pinheiro do Nascimento'

\section{ABSTRACT}

During the last years, Brazilian government control programs have detected an increase of Salmonella Heidelberg in poultry slaughterhouses a condition that poses a threat to human health However, the reasons remain unclear. Differences in genetic virulence profiles may be a possible justification. In addition, effective control of Salmonella is related to an efficient epidemiological surveillance system through genotyping techniques. In this context, the aim of this study was the detection of 24 virulence-associated genes in $126 \mathrm{~S}$. Heidelberg isolates. We classified the isolates into 56 different genetic profiles. None of the isolates presented all the virulence genes. The prevalence of these genes was high in all tested samples as the lowest number of genes detected in one isolate was 10/24. The $\operatorname{lpf} A$ and $\operatorname{csg} A$ (fimbriae), invA and $\operatorname{sivH}$ (TTSS), and $m s g A$ and tolC (intracellular survival) genes were present in $100 \%$ of the isolates analyzed. Genes encoding effector proteins were detected in the majority of $\mathrm{SH}$ isolates. No single isolate had the sefA gene. The pefA gene was found in only four isolates. We have also performed a screening of genes associated with iron metabolism: $88.9 \%$ of isolates had the $i r o N$ geneand $79.4 \%$ the sitC gene. Although all the isolates belong to the same serotype, several genotypic profiles were observed. These findings suggest that there is a diversity of $S$. Heidelberg isolates in poultry products. The fact that a single predominant profile was not found in this study indicates the presence of variable sources of contamination caused by SH. The detection of genetic profiles of Salmonella strains can be used to determine the virulence patterns of SH isolates.

KEYWORDS: Salmonellosis. Salmonella Heidelberg. Poultry. PCR. Virulence genes.

\section{INTRODUCTION}

Salmonella spp. is one of the main pathogens causing foodborne bacterial infections in humans and poultry products are the main sources of bacterial contamination ${ }^{1}$. The presence of this microbiological hazard affects negatively the poultry industry. Brazilian products of avian origin are exported to five continents. These poultry products should meet certain sanitary requirements of control and certification in order for this trade to occur properly. The control of Salmonella spp. in slaughterhouses is strict. In addition to having its relevance as a cause of foodborne disease, this bacterial pathogen has a major economic impact causing great losses to the domestic market and to export as well ${ }^{2}$.

It is worth mentioning that the performance of the Brazilian government in programs aimed to control S. enteritidis and S. typhimurium in food processing led to the reduction of their prevalences. In contrast, during the last couple of 
years there has been an increase in the prevalence of other serotypes, as Salmonella Heidelberg ( $\mathrm{SH})$. SH is one of the most widely distributed serotypes worldwide and is among the ten Salmonella serotypes most frequently associated with human diseases ${ }^{3,4}$. In a retrospective study spanning three decades (between 1962 and 1991) carried out in Brazil, $S$. Heidelberg was identified in birds and poultry products $^{5}$. According to the Rapid Alert System for Food and Feed Safety Alerts (RASFF), $S$. Heidelberg was among the serotypes most often isolated in the years 2013, 2014, and $2016^{6}$.

The successful control of this microorganism is also related to efficient national epidemiological surveillance systems using genotyping and phenotyping techniques. This methodology helps to study characteristics of the various serotypes of Salmonella as the ability and the way the pathogen adapts to the host and to the environment, depending on the virulence of each strain. Among the Salmonella that cause foodborne infections in humans, $S$. Heidelberg has been shown to be more invasive compared to other serotypes that cause gastroenteritis. Systemic disease occurs in approximately $13 \%$ of the cases of $S$. Heidelberg infections ${ }^{7,8}$.

$S$. Heidelberg's increasing importance is due to the frequent development of resistance to antimicrobial drugs, limiting treatment options in cases of salmonellosis ${ }^{9}$ and leading to a number of studies on this subject, carried out by many researchers around the world. The main issues are closely related to the pathogenicity of the microorganisms as they depend on a number of factors, including virulence factors of each strain, the serotype involved, the amount of inoculum, virulence factors expressed by the microorganism and the immunological status of the host. Therefore, Salmonella spp. may cause a broad spectrum of clinical diseases that vary in severity ranging from a mild gastrointestinal infection to a severe systemic illnesses ${ }^{10}$.

Virulence factors are encoded by a number of genes located on the bacterium own chromosome, the socalled housekeeping genes, which give specific and basic characteristics to bacteria from the same family. These genes can be found in the so-called pathogenicity islands, or in mobile genetic elements such as transposons, plasmids and bacteriophages ${ }^{11-13}$. These genes confer advantages for bacteria such as adaptation to the host cell, resistance to antimicrobials and the ability to overcome host defense mechanisms.

The increase in the occurrence of $\mathrm{SH}$ in food products and in SH-related infections is of concern to Brazilian authorities, since SH control and elimination from poultry farms is a major problem (data not shown). Changes in the acquisition of genes by SH strains have been reported in other animal species and have been considered as important factors that may have contributed to the increase of virulence ${ }^{14}$. In this context, the present study aimed to screen the 24 genes associated with virulence of SH isolates by polymerase chain reaction (PCR).

\section{MATERIALS AND METHODS}

\section{Bacterial isolates}

The present study was carried out at the Laboratory of Bacteriology and Mycology, Veterinary Hospital of the Universidade de Passo Fundo (UPF) and Centro de Diagnostico e Pesquisa em Patologia Aviaria (CDPA) of the Universidade Federal do Rio Grande do Sul (UFRGS). A total of 126 Salmonella Heidelberg isolates from chilled and frozen chicken carcasses collected in 2015 in a poultry slaughterhouse and serotyped at the Osvaldo Cruz Foundation, Rio de Janeiro State, Brazil, were used in this study. These samples were kindly provided by Eduardo Cesar Tondo from the Institute of Food Science and Technology (ICTA) at UFRGS, Porto Alegre, Rio Grande do Sul State, Brazil. Samples were stored at $-20^{\circ} \mathrm{C}$ in a Brain Heart Infusion (BHI) broth with $20 \%$ glycerol. All stored isolates were reactivated and re-identified biochemically and serologically.

\section{Polymerase chain reaction (PCR)}

The molecular characterization of the 126 isolates of $S$. Heidelberg consisted of screening 24 genes involved in the virulence and pathogenicity of Salmonella spp. The following genes were screened in this study: invA, hilA, lpfA, lpfC, sefA, csgA [agfA], spvB, pefA, sopE, avrA, sivH, orgA, $\operatorname{prg} H, \operatorname{spaN}, \operatorname{tol} C, \operatorname{sip} B, \operatorname{sit} C, \operatorname{pag} C, m s g A$, spiA, iroN, sopB, $c d t B$ and sifA. DNA extraction was carried out through a heat treatment ${ }^{15}$. Only samples with at least $10 \mathrm{ng}$ of DNA were subjected to amplification. The method used was adapted from the technique published by Borges et al. ${ }^{15}$. Amplifications were performed in a MaxPro Swift thermocycler (Esco, Singapore) and afterwards electrophoresis was performed in $1.5 \%$ agarose gels stained with ethidium bromide. The analysis of the amplified products was performed by the visualization of the corresponding bands under ultraviolet light using a transilluminator (MacroVue, Pharmacia LKB Biotechnologies, Uppsala, Sweden) coupled to digital photodocumentation of these bands/transilluminated gels (Alpha Innotche, San Leandro, USA). The sequence of primers, as well as the size of amplicons and the reference of protocols for detection of each gene are presented in 
Table 1. Cycling conditions and reaction mixtures $(25 \mu \mathrm{L}$ of total volume) were previously described ${ }^{16}$. Standard strains of Mannheimia haemolytica (ATCC 29694) and Salmonella enteritidis (ATCC 13076) were used as negative and positive control, respectively. PCR assays were repeated three times.

\section{RESULTS}

The absolute and relative frequencies of the 24 investigated virulence-associated genes grouped according to their respective functions are shown in Table 2. The 126

Table 1 - Salmonella spp. virulence genes $(n=24)$, sequence of primers to amplify Salmonella Heidelberg virulence genes, the amplicons' molecular weight (in base pairs) and the corresponding references.

\begin{tabular}{|c|c|c|c|}
\hline Genes & Primers sequences $\left(5^{\prime}-3^{\prime}\right)$ & Base pair (bp) & References \\
\hline IpfC & $\begin{array}{l}\text { GCCCCGCCTGAAGCCTGTGTTGC } \\
\text { AGGTCGCCGCTGTTTGAGGTTGGATA }\end{array}$ & 641 & 26 \\
\hline$s p v B$ & $\begin{array}{l}\text { CTATCAGCCCCGCACGGAGAGCAGTTTTTA } \\
\text { GGAGGAGGCGGTGGCGGTGGCATCATA }\end{array}$ & 717 & 26 \\
\hline pefA & $\begin{array}{l}\text { GCGCCGCTCAGCCGAACCAG } \\
\text { GCAGCAGAAGCCCAGGAAACAGTG }\end{array}$ & 157 & 26 \\
\hline $\operatorname{org} A$ & $\begin{array}{l}\text { CAGCGCTGGGGATTACCGTTTTG } \\
\text { TTTTTGGCAATGCATCAGGGAACA }\end{array}$ & 255 & 26 \\
\hline $\operatorname{prgH}$ & $\begin{array}{l}\text { GCCCGAGCAGCCTGAGAAGTTAGAAA } \\
\text { TGAAATGAGCGCCCCTTGAGCCAGTC }\end{array}$ & 756 & 26 \\
\hline spaN & $\begin{array}{l}\text { AAAAGCCGTGGAATCCGTTAGTGAAGT } \\
\text { CAGCGCTGGGGATTACCGTTTTG }\end{array}$ & 504 & 26 \\
\hline tolC & $\begin{array}{l}\text { TACCCAGGCGCAAAAAGAGGCTATC } \\
\text { CCGCGTTATCCAGGTTGTTGC }\end{array}$ & 161 & 26 \\
\hline $\operatorname{sip} B$ & $\begin{array}{l}\text { GGACGCCGCCCGGGAAAAACTCTC } \\
\text { ACACTCCCGTCGCCGCCTTCACAA }\end{array}$ & 875 & 26 \\
\hline sitC & $\begin{array}{l}\text { CAGTATATGCTCAACGCGATGTGGGTCTCC } \\
\text { CGGGGCGAAAATAAAGGCTGTGATGAAC }\end{array}$ & 768 & 26 \\
\hline pagC & $\begin{array}{l}\text { CGCCTTTTCCGTGGGGTATGC } \\
\text { GAAGCCGTTTATTTTTGTAGAGGAGATGTT }\end{array}$ & 454 & 26 \\
\hline$m s g A$ & $\begin{array}{l}\text { GCCAGGCGCACGCGAAATCATCC } \\
\text { GCGACCAGCCACATATCAGCCTCTTCAAAC }\end{array}$ & 189 & 26 \\
\hline spiA & $\begin{array}{l}\text { CCAGGGGTCGTTAGTGTATTGCGTGAGATG } \\
\text { CGCGTAACAAAGAACCCGTAGTGATGGATT }\end{array}$ & 550 & 26 \\
\hline iroN & $\begin{array}{l}\text { CCGCGTTATCCAGGTTGTTGC } \\
\text { ACTGGCACGGCTCGCTGTCGCTCTAT }\end{array}$ & 1205 & 26 \\
\hline $\operatorname{sop} B$ & $\begin{array}{l}\text { CGGACCGGCCAGCAACAAAACAAGAAGAAG } \\
\text { TAGTGATGCCCGTTATGCGTGAGTGTATT }\end{array}$ & 220 & 26 \\
\hline cdtB & $\begin{array}{l}\text { ACAACTGTCGCATCTCGCCCCGTCATT } \\
\text { CAATTTGCGTGGGTTCTGTAGGTGCGAGT }\end{array}$ & 268 & 26 \\
\hline sifA & $\begin{array}{l}\text { TTTGCCGAACGCGCCCCCACACG } \\
\text { GTTGCCTTTTCTTGCGCTTTCCACCCATCT }\end{array}$ & 449 & 26 \\
\hline IpfA & $\begin{array}{l}\text { CTTTCGCTGCTGAATCTGGT } \\
\text { CAGTGTTAACAGAAACCAGT }\end{array}$ & 250 & 29 \\
\hline $\operatorname{csg} A(\operatorname{agfA})$ & $\begin{array}{l}\text { TCCACAATGGGGCGGCGGCG } \\
\text { CCTGACGCACCATTACGCTG }\end{array}$ & 350 & 30 \\
\hline $\operatorname{sef} A$ & $\begin{array}{l}\text { GATACTGCTGAACGTAGAAGG } \\
\text { GCGTAAATCAGCATCTGCAGTAGC }\end{array}$ & 488 & 31 \\
\hline $\operatorname{inv} A$ & $\begin{array}{l}\text { GTGAAATTATCGCCACGTTCGGGCAA } \\
\text { TCATCGCACCGTCAAAGGAACC }\end{array}$ & 284 & 31 \\
\hline hilA & $\begin{array}{l}\text { CTGCCGCAGTGTTAAGGATA } \\
\text { CTGTCGCCTTAATCGCATGT }\end{array}$ & 497 & 32 \\
\hline avrA & $\begin{array}{l}\text { GTTATGGACGGAACGACATCGG } \\
\text { ATTCTGCTTCCCGCCGCC }\end{array}$ & 385 & 33 \\
\hline sopE & $\begin{array}{l}\text { ACACACTTTCACCGAGGAAGCG } \\
\text { GGATGCCTTCTGATGTTGACTGG }\end{array}$ & 398 & 33 \\
\hline $\operatorname{sivH}$ & $\begin{array}{l}\text { CAGAATGCGAATCCTTCGCAC } \\
\text { GTATGCGAACAAGCGTAACAC }\end{array}$ & 763 & 34 \\
\hline
\end{tabular}


isolates of $S$. Heidelberg showed 56 different genotypic profiles based on the detection of genes associated with virulence and pathogenicity. It is worth noting that none of the isolates evaluated had all the 24 screened genes. However, the prevalence of these genes was high since the lowest number of genes detected in one isolate was 10/24. The lpfA and $\operatorname{csg} A$ (fimbriae), invA and $\operatorname{sivH}$ (type III secretion system) and $m s g A$ and tolC (intracellular survival) genes were present in $100 \%$ of the analyzed isolates (Table 2).

\section{DISCUSSION}

Virulence factors are encoded by a number of genes and may be located on the bacterium's own chromosome. These molecules may be present in the so-called pathogenicity islands, or in mobile genetic elements ${ }^{12,13}$. It is widely reported that when these genes are present and especially when gene expression is induced, they confer a number of advantages to bacteria.

Fimbrial virulence genes play an important role in bacterial pathogenicity since they promote bacterial binding to intestinal epithelial cells (enterocytes) ${ }^{17}$. In the present study, the fimbrial genes $\operatorname{sefA}, \operatorname{lpfA}, \operatorname{lpfC}, \operatorname{csg} A$, and pefA were analyzed; $100 \%$ of the isolates had the $\operatorname{lpf} A$ and $\operatorname{csg} A$ genes (Table 2). The lpfA gene encodes the major subunit of long polar fimbriae which promotes the adhesion of bacteria to the epithelial cells lining the Peyer's patches of the intestine conferring cross-immunity between serotypes ${ }^{18-20}$.

Fine aggregative fimbriae are essential to the synthesis of extracellular polymeric substance (EPS) which is involved in biofilm formation and environmental persistence. The $\operatorname{csg} A$ (formerly agfA) gene is one of the genes encoding the presence of these fimbriae which also have properties related to pathogenesis and auto-aggregation (increased survival), are pro-inflammatory and increase invasion of eukaryotic cells ${ }^{19}$. The $\operatorname{csg} A$ gene is also associated with bacterial adhesion to various inert surfaces, including those used in food production. For this reason, it is also considered an important gene for the production of biofilms and the maintenance of the bacteria in the environment ${ }^{20,21}$. Other researchers have reported a high detection frequency of the $\operatorname{csg} A$ gene in different serotypes of Salmonella spp. ${ }^{22-24}$. Our findings corroborate theirs. Doran et al. ${ }^{25}$ analyzed 604 strains of Salmonella belonging to different serotypes. These authors noted that 603 samples presented the $\operatorname{csg} A$ gene, suggesting that this gene is well conserved among serotypes.

No isolate had the sefA gene. The pefA gene was found in four isolates only (Table 2). The pefA gene may be absent

Table 2 - Absolute and relative frequencies of 24 virulence genes screened by PCR in Salmonella Heidelberg isolates.

\begin{tabular}{|c|c|c|c|c|}
\hline Gene Function & & Gene & $\begin{array}{l}\text { Absolute frequencies } \\
\qquad(n=126)\end{array}$ & $\begin{array}{l}\text { Relative frequencies } \\
(\%)\end{array}$ \\
\hline \multirow{5}{*}{ Fimbriae } & & sefA & 0 & 0 \\
\hline & & IpfA & 126 & 100 \\
\hline & & IpfC & 107 & 84.9 \\
\hline & & $\operatorname{agfA}$ & 126 & 100 \\
\hline & & pefA & 4 & 3.17 \\
\hline \multirow{11}{*}{ TTSS } & & $\operatorname{sip} B$ & 91 & 72.2 \\
\hline & & $\operatorname{inv} A$ & 126 & 100 \\
\hline & Structure & $\operatorname{org} A$ & 84 & 66.7 \\
\hline & & prgH & 65 & 51.6 \\
\hline & & spaN & 103 & 81.7 \\
\hline & & avrA & 124 & 98.4 \\
\hline & & sopE & 112 & 88.9 \\
\hline & Effector protein & sopB & 123 & 97.6 \\
\hline & & sivH & 126 & 100 \\
\hline & & sifA & 108 & 85.7 \\
\hline & Regulatory protein & hilA & 84 & 66,6 \\
\hline \multirow{4}{*}{$\begin{array}{l}\text { Survival inside cells } \\
\text { (macrophages) }\end{array}$} & & pagC & 120 & 95.2 \\
\hline & & spiA & 120 & 95.2 \\
\hline & & $m s g A$ & 126 & 100 \\
\hline & & tolC & 126 & 100 \\
\hline Plasmid & & $s p v B$ & 1 & 0.79 \\
\hline \multirow{2}{*}{ Iron metabolism } & & iroN & 112 & 88.9 \\
\hline & & sitC & 100 & 79.4 \\
\hline Toxins & & $c d t B$ & 11 & 8.73 \\
\hline
\end{tabular}


in some salmonellae due to the original localization of the gene, which is plasmidial. Plasmids are present in only a few serotypes of Salmonella spp. ${ }^{26}$. It is worth mentioning that the sefA gene is considered one of the target genes for detecting and serotyping $S$. enteritidis ${ }^{22}$. The acquisition and loss of specific fimbrial operons may be one of the mechanisms by which different Salmonella serotypes have been able to adapt to an increasing number of hosts ${ }^{27}$. Studies have shown that fimbriae have tropism by different cell types in distinct hosts. For this reason, it is possible that the absence of certain fimbriae could alter the virulence of the $\operatorname{strain}^{19}$.

All SH (100\%) presented the invA gene which is related to host recognition and internalization of the bacterium during invasion of epithelial cells. This gene is associated with the structure of TTSS (Type Three Secretion System) and is considered the main target gene for the detection of strains belonging to this genus by $\mathrm{PCR}^{22,28}$. In this study, $66.6 \%$ of the SH isolates presented the hilA gene. This gene encodes the hyperinvasive protein hilA which is the main regulator of TTSS components and also encodes SPI- $1^{29}$. This gene is related to the cell recognition and invasion process. Both the hilA gene and invA gene are considered target genes for the detection of the genus Salmonella ${ }^{28}$.

The $\operatorname{org} A, \operatorname{sip} B, \operatorname{prg} H$, and $\operatorname{spaN}$ genes are also related to the structure of these systems ${ }^{26}$. In the SH isolates, the frequencies of the $\operatorname{spaN}$ gene (81.7\%) and $\operatorname{sipB}(72.2 \%)$ were high, followed by other genes with lower frequencies. The spaN gene is one of the 12 genes that form a cluster associated with host invasion properties ${ }^{30}$. Borges et al. ${ }^{24}$, reported the presence of $\operatorname{org} A, \operatorname{sip} B, \operatorname{prg} H$, and $\operatorname{spaN}$ genes in different Salmonella serotypes. These authors noted that the spaN gene is associated with strains isolated from poultry sources and is a potential epidemiological marker of Salmonella of avian origin.

Genes encoding the effector proteins secreted by TTSS, such as: $s i f \mathrm{~A}, a v r \mathrm{~A}, \operatorname{sop} \mathrm{E}, s o p \mathrm{~B}$ e and $s i v \mathrm{H}$ were detected in the majority of tested SH strains (Table 2). It is important to search for these genes because the detection of possible changes in the repertoire of the resulting proteins can mean changes in the ability of Salmonella serotypes to adapt to new hosts, allowing them to become emergent and may be related to the appearance of salmonellosis outbreaks ${ }^{31}$.

In order to assess survival rate and inside cells, especially the ability to survive within macrophages, the following genes were investigated in our study: $m s g A$, spiA, pagC, and tolC. We detected the msgA and tolC genes in $100 \%$ of the tested isolates (126 SH samples). The pagC and spiA genes were detected in $95.2 \%$ of the analyzed specimens (Table 2). It is worth mentioning that the spiA gene is also related to the ability of the isolates to produce biofilms. Our findings corroborate those published by Borges et al. ${ }^{24}$ who detected the presence of the $m s g A$ gene in $100 \%$ of the tested samples whereas the spiA and pagC genes showed a frequency of $93.8 \%$ in these samples. Rizzo et al. ${ }^{23}$ detected the genes $m s g A$, spiA, tolC and pagC in all of the Salmonella Gallinarum strains.

Only one SH isolate had the $s p v B$ gene $(0.79 \%)$. This gene is of plasmid origin, is associated with the Salmonella virulence plasmid and is responsible for the maintenance and bacterial survival within the cell ${ }^{31}$. The low frequency of this gene was expected among $\mathrm{SH}$, since the presence of plasmids in Salmonella is closely related to the involved serotype. Its detection is more common in serotype Enteritidis $^{32,33}$. According to Rizzo et al. ${ }^{23}$ the $s p v B$ gene was expressed in $80 \%$ (12/15) of the serotype Gallinarum samples tested showing that this gene may also be common to other serotypes. DNA extraction by heat treatment could have interfered with the detection of this gene. However, the use of DNA samples extracted through commercial kits presented similar results (unpublished data).

In the present study, we investigated genes associated with iron metabolism, including the iroN gene and the sitC gene. Of the analyzed SH isolates, $88.9 \%$ presented the iroN gene whereas $79.4 \%$ had the $s i t C$ gene (Table 2). Bacteria rely on a number of mechanisms and molecules to acquire iron for survival. The sit $C$ gene encodes membrane proteins in bacterial cell which are associated with iron uptake. In contrast, iroN gene encodes proteins that function as receptors of siderophores ${ }^{26,34}$. After cell invasion, Salmonella spp. finds an environment with restricted amount of iron, an essential element for their survival and growth within the host cell ${ }^{26,34}$. Consequently, bacteria have developed a variety of iron procurement systems, which are generally redundant and are not simultaneously expressed. For this reason, the absence of these genes is unlikely to be a problem for the survival and multiplication of Salmonella within the host cell. The $i r o N$ gene is positively associated with the serotype Heidelberg ${ }^{24}$. According to the study carried out by Borges et al..$^{24}$, in which different Salmonella serotypes were analyzed, the absence of the iro $N$ gene and the presence of the spaN gene are associated with bacterial strains from poultry sources.

The $c d t B$ gene is one of the genes encoding toxins that induce apoptosis of infected cells. Of the tested isolates, only $11(8.7 \%)$ had this gene. The finding of a low frequency $c d t B$ gene is in agreement with previous studies in which different serotypes of Salmonella spp. were analyzed ${ }^{23,24}$. According to the published literature, this gene is possibly restricted to some serotypes of Salmonella $\mathrm{spp}^{26}$.

Some results were unexpected, such as the low frequency of hilA, $\operatorname{org} A$ and $\operatorname{prg} H$ genes, presenting 
differences in relation to the molecular profiles found in SH strains isolated in Brazil between 1996 and 2006 24. Gene frequency variation and genetic profile may be influencing the survival and multiplication capacity of the strains over the years, subsequently leading to an increase in the frequency of this serotype isolated from poultry sources in Southern Brazil. Aravena et al. ${ }^{27}$ analyzed SH strains isolated in Chile between 2006 and 2011 and did not observe these variations. However, Antony et al. ${ }^{14}$ detected the operon $s a f A B C D$ in strains isolated in USA between 2009 and 2017. This operon has been previously described as absent in this serotype ${ }^{14}$. These results support the theory that modification in genetic profile of circulating SH strains are a possible reason for the increased detection of this particular serotype. Further studies are needed to confirm this hypothesis. A preliminary analysis performed by our laboratory (data not shown) demonstrated that strains isolated in Brazil in 2016 and 2017 presented a greater genetic variability when compared to those isolated until $2006^{28}$. In more recent isolates, two new ribotypes were identified. The emergence of two new ribotypes may indicate a trend in changing circulating clones, which could be one of the reasons for the increased frequency of this serotype isolation ${ }^{28}$.

The knowledge on Salmonella serotypes and detection of genetic profiles of these bacterial pathogens can be used to determine different virulence patterns of isolates. These data allow a better understanding of the characteristics of each serotype and the establishment of criteria to predict the virulence of these microorganisms. The information generated in these studies would help and improve Salmonella control strategies in the food industry, as well as the control measures for the prevention of salmonellosis in humans.

In the present study, we noted that among the isolates of $S$. Heidelberg tested there are genotypic profile differences. This finding suggests the presence of a great diversity of $S$. Heidelberg isolates in poultry products. The fact that a single predominant profile was not found in our survey indicates that there are a variety of S. Heidelberg contamination sources in the food industry.

\section{CONFLICT OF INTERESTS}

All authors state that there is no conflict of interests regarding the publication of this manuscript.

\section{ACKNOWLEDGMENTS}

The authors of this manuscript gratefully acknowledges Eduardo Cesar Tondo from the Institute of Food Science and
Technology (ICTA) at UFRGS, Porto Alegre, Rio Grande do Sul State, Brazil who kindly provided the Salmonella Heidelberg samples for this study.

\section{REFERENCES}

1. Vieira A, Jensen AR, Pires SM, Karlsmose S, Wegener HC, Wong DL. WHO Global Foodborne Infections Network Country Databank: a resource to link human and non-human sources of Salmonella. In: Proceedings of the $12^{\text {th }}$ Symposium of the International Society for Veterinary Epidemiology and Economics; 2009 Aug 10-14; Durban, South Africa.

2. Associação Brasileira de Proteína Animal. 2017: relatório anual. São Paulo: ABPA; 2017. [cited 2019 Jun 27]. Available from: http://abpa-br.com.br/storage/files/3678c_final_abpa_ relatorio_anual_2016_portugues_web_reduzido.pdf

3. Grimont PA, Weill FX. Antigenic formulae of the Salmonella serotypes. Paris: WHO Collaborating Centre for Reference and Research on Salmonella; 2007.

4. Centers for Disease Control and Prevention. National Enteric Disease Surveillance: Salmonella annual report, 2013. [cited 2019 Jun 27]. Available from: https://www.cdc.gov/ nationalsurveillance/pdfs/salmonella-annual-report-2013508c.pdf

5. Hofer E, Silva Filho SJ, Reis EM. Prevalência de sorovares de Salmonella isolados de aves no Brasil. Pesq Vet Bras. 1997;17:55-62.

6. The Rapid Alert System for Food and Feed. RASFF annual report 2016. Luxembourg: Publications Office of the European Union; 2017. [cited 2019 June 27]. Available from: https://ec.europa. eu/food/sites/food/files/safety/docs/rasff_annual_report_2016. pdf

7. Jones TF, Ingram A, Cieslak PR, Vugia DJ, Tobin D'Angelo M, Hurd S, et al. Salmonellosis outcomes differ substantially by serotype. J Infect Dis. 2008;198:109-14.

8. Dutil L, Irwin R, Finley R, Ng LK, Avery B, Boerlin P, et al. Ceftiofur resistance in Salmonella enterica serotype Heidelberg from chicken meat and humans, Canada. Emerg Infect Dis. 2010;16:48-54.

9. Public Health Agency of Canada. Salmonella Heidelberg : ceftiofur-related resistance in human and retail chicken isolates. [cited 2019 Jun 27]. Available from: http://www.phac-aspc. gc.ca/cipars-picra/heidelberg/pdf/heidelberg_e.pdf

10. Beceiro A, Tomás M, Bou G. Antimicrobial resistance and virulence: a successful or deleterious association in the bacterial world? Clin Microbiol Rev. 2013;26:185-230.

11. Groisman EA, Ochman H. Pathogenicity islands: bacterial evolution in quantum leaps. Cell. 1996;87:791-4.

12. Marcus SL, Brumell JH, Pfeifer CG, Finlay BB. Salmonella pathogenicity islands: big virulence in small packages. Microbes Infect. 2000;2:145-56. 
13. van Asten AJ, van Dijk JE. Distribution of "classic" virulence factors among Salmonella spp. FEMS Immun Med Microbiol. 2005;44:251-9.

14. Antony L, Behr M, Sockett D, Miskimins D, Aulik N, ChristopherHennings J, et al. Genome divergence and increased virulence of outbreak associated Salmonella enterica subspecies enterica serotype Heidelberg. Gut Pathog. 2018;10:53.

15. Borges KA, Furian TQ, Souza SN, Tondo EC, Streck AF, Salle CT, et al. Spread of a major clone of Salmonella enterica serotype Enteritidis in poultry and in salmonellosis outbreaks in Southern Brazil. J Food Prot. 2017;80:158-63.

16. Borges KA, Furian TQ, Souza SN, Menezes R, Salle CT, Moraes HL, et al. Phenotypic and molecular characterization of Salmonella Enteritidis SE86 isolated from poultry and salmonellosis outbreaks. Foodborne Pathog Dis. 2017;14:74254.

17. van der Velden AW, Bäumler AJ, Tsolis RM, Heffron F. Multiple fimbrial adhesions are required for full virulence of Salmonella Typhimurium in mice. Infect Immun. 1998;66:2803-8.

18. Ginocchio CC, Galán JE. Functional conservation among members of the Salmonella Typhimurium invA family of proteins. Infect Immun. 1995;63:729-32.

19. Darwin KH, Miller VL. Molecular basis of the interaction of Salmonella with the intestinal mucosa. Clin Microbiol Rev. 1999;12:405-28

20. Gibson DL, White AP, Rajotte CM, Kay WW. AgfC and AgfE facilitate extracellular thin aggregative fimbriae synthesis in Salmonella enteritidis. Microbiology. 2007;153:1131-40.

21. Austin JW, Sanders G, Kay WW, Collinson SK. Thin aggregative fimbriae enhance Salmonella enteritidis biofilm formation. FEMS Microbiol Lett. 1998;162:295-301.

22. Borges KA, Furian TQ, Borsoi A, Moraes HL, Salle CT, Nascimento VP. Detection of virulence-associated genes in Salmonella Enteritidis isolates from chicken in South of Brazil. Pesq Vet Bras. 2013;33:1416-22.

23. Manto L, Rizzo NN, Webber B, Borges KA, Silva AP, Pottker ES, et al. Virulence genotypic profile of Samonella Gallinarum. In: $29^{\circ}$ Congresso Brasileiro de Microbiologia; 2017 Oct 22-25; Foz do Iguaçu, Brasil.

24. Borges KA, Furian TQ, Souza SN, Salle CT, Moraes HL, Nascimento VP. Antimicrobial resistance and molecular characterization of Salmonella enterica serotypes isolated from poultry sources in Brazil. Braz J Poult Sci. 2019;21:eRBCA-2019-0827.
25. Doran JL, Collinson SK, Clouthier SC, Cebula TA, Walter C, Koch WH, et al. Diagnostic potential of sefA DNA probes to Salmonella enteritidis and certain other O-serogroup D1 Salmonella serotypes. Mol Cell Probes. 1996;10:233-46.

26. Skyberg JA, Logue CM, Nolan LK. Virulence genotyping of Salmonella spp. with multiplex PCR. Avian Dis. 2006;50:7781.

27. Aravena C, Valencia B, Villegas A, Ortega M, Fernández RA, Araya P, et al. Caracterización de cepas clínicas y ambientales de Salmonella enterica subsp. enterica serovar Heidelberg aisladas en Chile. Rev Med Chile. 2019;147:24-33.

28. Borges KA, Furian TQ, Almeida AS, Salle CT, Moraes HL, Nascimento VP. Caracterização fenotípica e molecular de cepas de Salmonella Heidelberg isoladas de fontes avícolas. In: Anais do $5^{\circ}$ Congresso e Feira Brasil Sul de Avicultura, Suinocultura e Laticínios: Feira de Equipamentos. Serviços e Inovação; 2016 Nov 22; Porto Alegre, Brasil.

29. Bäumler AJ, Heffron F. Identification and sequence analysis of lpfABCDE, a putative fimbrial operon of Salmonella typhimurium. J Bacteriol. 1995; 177:2087-97

30. Doran JL, Collinson SK, Burian J, Sarlós G, Todd EC, Munro CK, et al. DNA-based diagnostic tests for Salmonella species targeting agfA, the structural gene for thin, aggregative fimbriae. J Clin Microbiol. 1993;31:2263-73.

31. Oliveira SD, Santos LR, Schuch DM, Silva AB, Salle CT, Canal CW. Detection and identification of Salmonella from poultryrelated samples by PCR. Vet Microbiol. 2002;87:25-35.

32. Guo X, Chen J, Beuchat LR, Brackett RE. PCR detection of Salmonella enterica serotype Montevideo in and on raw tomatoes using primers derived from hilA. Appl Environ Microbiol. 2000;66:5248-52.

33. Prager R, Rabsch W, Streckel W, Voigt W, Tietze E, Tschäpe H. Molecular properties of Salmonella enterica serotype paratyphi B distinguish between its systemic and its enteric pathovars. J Clin Microbiol. 2003;41:4270-8.

34. Kingsley RA, Humphries AD, Weening EH, De Zoete MR, Winter S, Papaconstantinopoulou A, et al. Molecular and phenotypic analysis of the CS54 island of Salmonella enterica serotype typhimurium: identification of intestinal colonization and persistence determinants. Infect Immun. 2003;71:629-40. 